\title{
Business Fundamental And Financial Statements Training For Small Businessescommunities In Medan Marelan, North Sumatera Province
}

\author{
Dearlina Sinaga, Nainggolan, Juliper, Beslina Afriani Siagian \\ Faculty of Teacher Training and Education, University HKBP Nommensen Medan \\ dearlina.sinaga@uhn.ac.id, juliper.nainggolan@uhn.ac.id, beslinasiagian@uhn.ac.id
}

Abstract. Entrepreneurship is the application of innovation \& creativity to problem solving and to take advantage of the opportunities faced by others every day. Innovation and creativity become important capital in generating business opportunities that are able to improve the level of the economy both for themselves and for the wider community. The goal of the Community Partnership Program is to develop the community especially housewife and young women towards an economically independent community and help in creating innovative business opportunities in the form of utilizing plastic waste into economically valuable items and also making a bouquet of flannel-based flowers. The method used in the implementation of the Community Partnership Program is Demonstration. The planned activity starts with the design of basic entrepreneurship training modules, then training on processing of simple materials (plastic waste and flannel cloth), conducting product manufacturing assistance, followed by training on the preparation of simple financial statements. The output of this service is 1 . The community is able to process simple ingredients into products that have economic value 2 . The community is able to market products to consumers both directly and through social media 3. The community is able to prepare simple financial reports from the sale of products.

Keywords: Entrepreneurship, Flannel Bouquet, Plastic Trash, Financial Reports, Marketing 


\section{INTRODUCTION}

Entrepreneurship is an innovative and creative application to solve the problem through taking advantages of an opportunites faced by the people everyday. Innovation and creativity are the important asset in creating business opportunities that are able to increase the level of economic both for themselves or wider society. This has been one of the fields had been focused by our government in order to make enterpreneurs that are able to increase the national economic advancement. That is the reason why our government put that material as an obligatory material in the curriculum of higher education.

Indonesian National Qualification Framework (KKNI) is a framework of competition rank that could be able to equalize, synchronize, and integrate between education and work training and experience in order as a sign of working competence recognition due to the work structure in many field of working. Along with the function of KKNI, Faculty of Teacher Training and Education (FKIP) of Nommensen HKBP University, try to bear teachers who are competent, professional, solid lead and have an entrepreneur skill, and good character. Therefore, FKIP applied the contextual learning program that is not focus only on the theoretical study but also it is practically done in the practice of entrepreneurship by making a small bussiniss in campus. Besides, FKIP also held some educational events such education festival that tried to compete students' creativity in doing entrepreneurship. This event had a good response. It can be seen from there were so many entrepreneurship proposals that had registered in that competition. The result showed that there were three proposal counted as an inspirative, innovative and have promising bussines opportunities. Through this events, the students are expected to be able to develop great ideas to create business opportunity on wider society.

The partner of this community service is the people of Paya Pasir village that is one of the subdistrict in Medan Marelan. Most of the people on Paya Pasir village depend their income on the sea (fishermen). This program offers an income solution that can be reliable by the people except fishing. An income from fishing is still hard to be rely on because the unfriendly condition of sea and weather had be hard for the fishermen. Besides, sea activity is more related to men. Therefore, the skill in crafts is a solution that can be offered to the people or society, especially for mothers and young women. Thus, this program is expected to drive them earn an extra income.

Other than that, Paya Pasir village has their tourist attraction that is an artificial lake named Danau Siombak. This lake is visited by many Medan local tourists. As a 
tourist attraction, the area of Danau Siombak are often visited by many people or society that want to enjoy the beouty of that lake and not a few of the visitors throw the trash around the lake. Plastic trashs are the most trash found on that area. It is the most dangerous trash that can threat the ecosystem because plastics are difficult to be proceesed on the ground. The lack of attention and awareness of the environment is the new threat faced by many area. Concerning of this situation is the turning point to find a solution that can give a positive impact not only for the environment but also be something that is useful for the society. The reuse of plastic trash into an artwork is the offered program for the society. The socialization about the reuse of plastic trash is expected to squeeze the trash around. Beside the plactic creation, the trend phenomenon on the teenager is the flannel flower bouquet.

\subsection{Significance of the study}

The result of this society partner program is to give an additional knowledge and ability in recycling the plastic trash and flannel into a product with higher economic value. This can be a modal especially for mothers and young women to create bussines opportunity. Besides the companionship in the process of making the product from plastic tras and flannel, this program also provided the society with how to make a simple finance report. This was aimed to help them making a simple financial report of the cost and income that had get when they are able to sell the product.

\subsection{Scope and Limitation of the study}

This partner program was held in the companion process of creating product from the plastic trash and flannel and making simple finance report for small business.

\subsection{Setting of the study}

This program was done in Medan Marelan subdistrict that consists of 2 out of 5 village namely Paya Pasir and Rengas Pulau village. This partner program was held on 2019 for one semester. Medan Marelan subdistrict is one out of 21 subdistricts on Medan, North Sumatra. It is located on north area of Medan and borderedline with Deli Serdang regency at the east, Medan Helvetia at the south, and Medan Belawan at the north. This Medan Marekan subdistrict is $44,47 \mathrm{~km} 2$ for wide and the total amount of people are 140.414. It has five villages namely, Kelurahan tanah 600, Kelurahan P.Pasir, Kelurahan Labuhan 
Deli, Kelurahan Rengas Pulau and Kelurahan Terjun. There is a developed tourist attraction that is an artificial lake called Danau Buatan Siombak. It is a beautiful artificial lake for $40 \mathrm{Ha}$ surround. It is only $15 \mathrm{~km}$ from the center of Medan. Eventhough it is not the center of industry, there are some of big warehouses and chicken field that provide the supply for an eggs for Medan in the Medan Marelan subdistrict.

\section{Research Designand Methodology}

This program was planned and done with educational method, training and companion approach. The planning of this program is on the steps below:

\begin{tabular}{|c|c|c|c|c|}
\hline No & Applied Activity & Approach & Target & $\begin{array}{c}\text { Partner } \\
\text { Particupation }\end{array}$ \\
\hline & $\begin{array}{l}\text { Giving the theory } \\
\text { and basic } \\
\text { understanding of } \\
\text { entrepreneurship }\end{array}$ & $\begin{array}{l}\text { Education } \\
\text { and seminar }\end{array}$ & $\begin{array}{l}\text { The society } \\
\text { understand the } \\
\text { definition, aim, } \\
\text { and function of } \\
\text { enterpreneurship }\end{array}$ & $\begin{array}{lr}\text { Providing } & \text { the } \\
\text { facilities } & \text { and } \\
\text { infrastructure } & \text { and } \\
\text { inviting } & \text { the } \\
\text { society } & \end{array}$ \\
\hline & $\begin{array}{l}\text { Training how to } \\
\text { reuse plastic trash }\end{array}$ & Trai & $\begin{array}{l}\text { Society are able } \\
\text { to reuse the } \\
\text { plactic trash into } \\
\text { an economical } \\
\text { product }\end{array}$ & $\begin{array}{lr}\text { Providing } & \text { the } \\
\text { facilities } & \text { and } \\
\text { infrastructure } & \text { and } \\
\text { inviting } & \text { the } \\
\text { society } & \\
\end{array}$ \\
\hline & $\begin{array}{l}\text { Training how to } \\
\text { make flannel } \\
\text { flower bouquet }\end{array}$ & Trai & $\begin{array}{l}\text { Society are able } \\
\text { to making a } \\
\text { flannel bouquet }\end{array}$ & $\begin{array}{lr}\text { Providing } & \text { the } \\
\text { facilities } & \text { and } \\
\text { infrastructure } & \text { and } \\
\text { inviting } & \text { the } \\
\text { society } & \end{array}$ \\
\hline & $\begin{array}{l}\text { Training how to } \\
\text { make a finance } \\
\text { report for the small } \\
\text { bussiness }\end{array}$ & Trai & $\begin{array}{l}\text { Society are able } \\
\text { to write and } \\
\text { report a simple } \\
\text { the financial data }\end{array}$ & $\begin{array}{lr}\text { Providing } & \text { the } \\
\text { facilities } & \text { and } \\
\text { infrastructure } & \text { and } \\
\text { inviting } & \text { the } \\
\text { society } & \end{array}$ \\
\hline & $\begin{array}{l}\text { Companion to sell } \\
\text { the training } \\
\text { products }\end{array}$ & $\begin{array}{l}\text { Companions } \\
\text { hip }\end{array}$ & $\begin{array}{l}\text { The society are } \\
\text { able to sell the } \\
\text { product }\end{array}$ & $\begin{array}{lr}\text { Providing } & \text { the } \\
\text { facilities } & \text { and } \\
\text { infrastructure } & \text { and } \\
\text { inviting } & \text { the } \\
\text { society } & \end{array}$ \\
\hline & Evaluating & Evaluasi & training & Providing \\
\hline
\end{tabular}




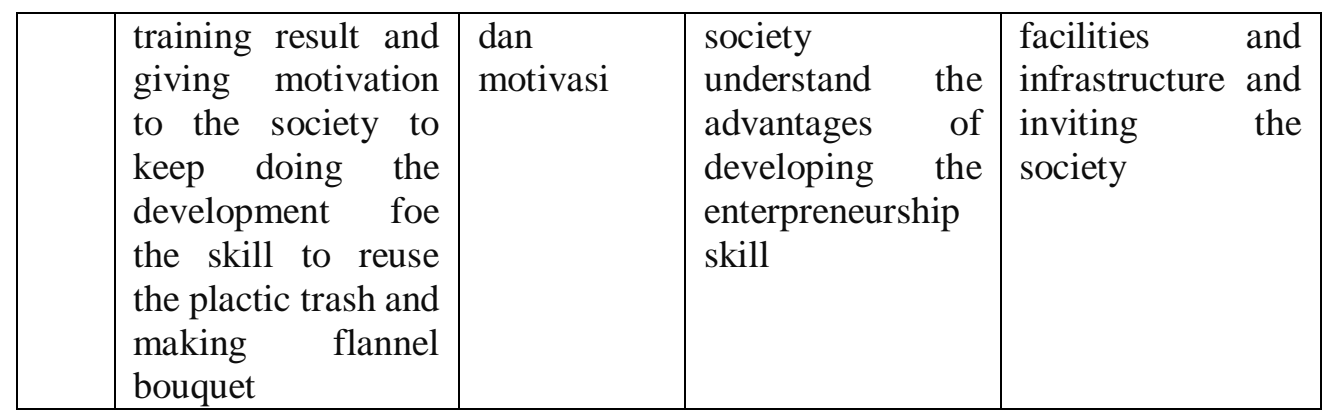

\subsection{Respondents of the study}

The participants of this partner program come from 2 villages in Medan Marelan subdistrict with the total of 50 participants. These participants are mothers and young women in the subdistrict.

\subsection{Data Collecting Procedure}

The implementation of this society partner profram in entrepreneurship was begun by observing Medan Marelan subdistrict. Besides the observation, the process of collecting the data done by interviewing the secretary of Medan Marelan subdistrict to get the information related to the problems as the results of the society undiscipline in managing the household waste especially plastic trash, and the necessity of training that need to be given to mothers and young women.

\section{Findings And Conclusions}

The society partner profram in entrepreneurship had was done in some stages, namely (1) socialization about the importance of entrepreneurship and the danger of plastic trash in form of presentation and speech by the source, (2) practice the reuse of plastic trash into an economical product, (3) practice making flannel product and (4) training in making the finance report of small business

In the socialization (1), the source had given the material related to the importance of entrepreneurship, remembering nowadays, in the free trade era 
and the industrial revolution 4.0, the competition is getting more competitive. This competitive competition will be a threat for who are not be able to compete each other. The unemployment is the important issues that must be handled by making a real step to cut the social gap in society. Becoming an enterpreneuris one of the solution that can be offered in order to imorove the economic ability of the society that getting down as the result of the fluctuative economic condition. Therefore, the society is expected to take a responsibility in supporting the national economic. Besides that, the source also educate the society about the danger of plastic trash and how to reuse it well. The society was reminded about theundiscipline and low of awareness in keeping the environment cleanliness. They was informed with the negative effect of plastic tras such as (a) climate change (b) environment pollution (c) harmful and (d) long process on the ground.

(2) The practice of reusing the plastic trash into an economical product. In this stage, mothers and young women was provided with the simple skill to reuse the plastic trash into an economical bag, this basic entrepreneurship training of reusing plastic trash has become a way to create new business opportunity that could be applied by mothers and young women in their environment. The economical innovative products are becoming the choice of most customer in the middle of import waves. (3) The practice of making flannel products. Recently, flannel has become a basic material used the most to make crafts, besides it is easy to find and has various colors, flannes is so economic. Nowadays, flannel are used to make various crafts such as doll, bouquet, box, etc. For this training, the mothers and youmg women were companied with students had make flannel bouquet. This flannel bouquet has become a favorite alternative for the customer for many special occasions because it is cheaper, long lasting, and interesting. The opportunity to sell the flannel products are good enough in which the marketing of this product can be done directly or using the social media. The companion process of making this product had be lead by the students by making groups. Every group was led by 3 students that ready to give direction and instruction in the process of making flannel bouquet. Each of the training participant was given the practice material provided by the committee that can be used to make flannel bouquet. Therefore, the training had not only textual but it has a real work that can be done directly. (3) Training in making finance report for 
small business. This training was aimed to give an understsanding for mothers and young women in managing and reporting the financial. Running the business can not be separated from making a good report of the company financial. This is important so that businessmen are able to understand their business income and expense in one period and the amount of profit they get. The material in this training consists of production cost to the selling price, and how to write the financial report. Based on the result of an interview done by the participants, they do not know or heard or done accounting, so by having this training they felt happy and can apply the knowledge directly not only for the business but also in their household. In the end of this partner program, the participants tell their gratitude and appreciation on this partner program on entrepreneurship. Along the days they joined the program they got a lot of knowledge that they have never had before. The training and companion that that got was able to change their mind set about the importance of entrepreneurship nowadays. Motivation and anthusiasm of society are bigger in starting the small business. The targeted society hope that this kind of program remain to be done with the new material so their knowledge and experience had be wider and they are able to actualize it in daily life. The regional government also get a lot of significance of this program and hope to have another program in the future.

\section{Recommendations}

By doing this partnership program especially in enterpreneurship, it is expected to be able to improve an edditional value of the society especially to create their own business opportunity and had provode another job vacancy for others.

\section{REFERENCES}

Adaja, T. (2013). Nigerian Youths and Social Alma, Buchari. 2016. Pengantar Bisnis . Bandung : Alfabeta.

http://ejournal.unima.ac.id/index.php/edupreneur diakses Juli 2018

Kasmir. 2006. Kewirausahaan. Jakarta: PT Raja Grafindo Persada. 
Ersina, Nuria. 2016. Penyuluhan Kewirausahaan, Tentang Peningkatan Pendapatan Melalui Bisnis Keluarga Kepada Perkumpulan Ibu-Ibu Arisan Warga RT. 1. Kelurahan Sukabumni Kecamatan Sukabumi Kota Bandar Lampung. Univeristas Bandar Lampung : Bandar Lampung

Peraturan Presiden Republik Indonesia No 8 Tahun 2012 tentang Kerangka Kualifikasi Nasional Indonesia, (http://kknikemenristekdikti.org/asset/pdf/perpres_no_8_tahun_2012_ttg_kkni.pdf)

Sinaga, Dearlina.2013.Kewirausahaan.Perdana Publishing : Medan

Suryana, 2010. Kewirausahaan, Pedoman Praktis, Kiat, dan Proses MenujuSukses. Salemba Empat, Jakarta 